\title{
USE OF CLINICAL INDICATORS IN THE EVALUATION OF PREVENTION AND CONTROL PRACTICES FOR BLOODSTREAM INFECTION ${ }^{1}$
}

\author{
Francisca Jane Gomes de Oliveira², Joselany Afio Caetano³, Viviane Martins da Silva ${ }^{4}$, Paulo César de \\ Almeida ${ }^{5}$, Andrea Bezerra Rodrigues ${ }^{6}$, Julianna Freitas Siqueira ${ }^{7}$
}

\footnotetext{
${ }^{1}$ Partial result from the thesis - Avaliação das práticas de prevenção e controle de infecção de corrente sanguínea, presented at the Programa de Pós-Graduação em Enfermagem (PEN) of the Universidade Federal do Ceará (UFC), in 2013.

${ }^{2}$ M.Sc. in Nursing. Nurse at the Monte Klinikum Hospital. Fortaleza, Ceará, Brazil. E-mail: jane3876@gmail.com

${ }^{3}$ Ph.D. in Nursing. Professor at the Departamento de Enfermagem and at PEN/UFC. Fortaleza, Ceará, Brazil. E-mail: joselany@ufc.br ${ }^{4}$ Ph.D. in Nursing. Professor at the Departamento de Enfermagem and at PEN/UFC. Fortaleza, Ceará, Brazil. E-mail: vivi@ufc.br

${ }^{5}$ Ph.D. in Nursing. Professor at the Departamento de Enfermagem and at PEN/UFC. Fortaleza, Ceará, Brazil. E-mail: pc@hotmail.com ${ }^{6}$ Ph.D. in Nursing. Professor at the Departamento de Enfermagem and at PEN/UFC. Fortaleza, Ceará, Brazil. E-mail: andrea@ufc.br

${ }^{7}$ M.Sc. in Nursing. Professor at the Departamento de Enfermagem of the Faculdade Integrada da Grande Fortaleza. Fortaleza, Ceará, Brazil. E-mail:juliannasiqueira@hotmail.com.br
}

\begin{abstract}
The aim of this study was to evaluate the compliance of the implemented prevention and control practices for central venous catheter-related bloodstream infection, through clinical indicators. An observational study, with a quantitative approach, was conducted. The case series was based on 2064 evaluations, conducted through direct observation and medical records, using a manual for evaluating the quality of cross-infection control practices. The results showed that the indicator for the registrations of the insertion and dwell time of the catheter had the highest overall compliance rate $(62.5 \%)$. The indicator related to hand hygiene, on the other hand, showed a null overall compliance rate. Strategies must be developed to ensure adherence to the prevention and control practices for central venous catheter-related bloodstream infection and periodic evaluations of working conditions must be implemented, in order to raise compliance rates.
\end{abstract}

DESCRIPTORS: Indicators. Catheter. Catheter-related infections. Cross-infection.

\section{O USO DE INDICADORES CLÍNICOS NA AVALIAÇÃO DAS PRÁTICAS DE PREVENÇÃO E CONTROLE DE INFECÇÃO DE CORRENTE SANGUÍNEA}

\begin{abstract}
RESUMO: O estudo objetivou avaliar a conformidade da realização das práticas de prevenção e controle de infecção de corrente sanguínea relacionada ao cateter venoso central, através de indicadores clínicos. Trata-se de um estudo observacional, com abordagem quantitativa. A casuística baseou-se em 2064 avaliações, realizadas através da observação direta e registro em prontuários, utilizando o manual de avaliação de qualidade das práticas de controle de infecção hospitalar. Os resultados mostraram que o indicador relativo ao registro de inserção e tempo de permanência do cateter apresentou maior índice de conformidade geral (62,5\%). Já o indicador relacionado à higienização das mãos apresentou índice de conformidade geral nulo. Existe a necessidade de elaborar estratégias que assegurem a adesão às práticas de controle e prevenção de infecção de corrente sanguínea relacionada ao cateter venoso central, bem como instituir avaliações periódicas das condições de trabalho, no sentido de elevar os índices de conformidade.
\end{abstract}

DESCRITORES: Indicadores. Cateter. Infecções relacionada a cateter. Infecção hospitalar.

\section{EL USO DE INDICADORES EN LA EVALUACIÓN DE LAS PRÁCTICAS CLÍNICAS PARA LA PREVENCIÓN Y CONTROL DE LA INFECCIÓN DEL TORRENTE SANGUÍNEO}

RESUMEN: El estudio pretende evaluar el cumplimiento de las prácticas para la prevención y control de la infección del torrente sanguíneo, relacionadas con el catéter venoso central a través de indicadores clínicos. Este es un estudio observacional, con un enfoque cuantitativo. La serie fue basada en las evaluaciones realizadas por 2064 observación directa y registro en registros médicos, utilizando el manual de evaluación de la calidad de las prácticas de control de infecciones hospital. Los resultados mostraron que el indicador en el insertar registro y tiempo de catéter mostró el mayor índice de cumplimiento global (62,5\%). El indicador relacionado con la higiene de las manos demostró ya índice general cumplimiento nulo. Hay que elaborar estrategias para garantizar el cumplimiento de las prácticas de control de la infección y prevención de la circulación sanguínea central venosa relacionada con el catéter, así como instituir las evaluaciones periódicas de las condiciones de trabajo, a fin de elevar las tasas de cumplimiento.

DESCRIPTORES: Indicadores. Catéter. Infecciones relacionadas con catéter. Infección intrahospitalaria. 


\section{INTRODUCTION}

Healthcare-associated infections (HAIs) are currently a challenge to health care, given the high mortality rate associated with their incidence, especially in intensive care units (ICU), which is the sector with the highest number of HAIs, due to factors conducive to their development, such as: prolonged hospital stay, use of mechanical ventilation, invasive procedures, patients' age, use of immunosuppressants and anti-infective agents, and patients' underlying diseases and nutritional conditions. ${ }^{1}$

Among these infections, bloodstream infections stand out, which are mainly caused by invasive devices, especially short-term central venous catethers, because they are kept longer, besides being manipulated several times a day to replenish fluids and electrolytes; therapy for transfusion of blood and its derivates, administration of intravenous drugs, including chemotherapy; parenteral nutrition; conducting therapeutic approaches and diagnostic techniques, such as hemodialysis; arterial and venous hemodynamic monitoring; and contrast infusion to view structures. ${ }^{2}$

The importance of central venous catheterrelated bloodstream infection, as a public health problem, motivated the improvement of monitoring standards. Over the past few years, studies on risk factors for central venous catheter-related bloodstream infection, development of new technologies and the improvement of central venous catheter insertion and maintenance techniques supported the development of guidelines for the control of these infections. ${ }^{3-5}$

Several studies have shown that it is possible to reduce central venous catheter (CVC)-related bloodstream infection rates to almost zero with a set of measures considered easy to apply and inexpensive, namely: standardization of norms for insertion of the catheter, sterile technique and care after insertion. ${ }^{2}$ Thus, continuing education programs for professionals responsible for the insertion and manipulation of intravascular catheters are one of the key strategies recommended by the Centers for Disease Control and Prevention to decrease the incidence of infections associated with the use of these devices. ${ }^{6}$

However, there have been observed, in practice, errors in handling the common central venous access, such as inadequate skin antisepsis, failure to observe the friction time, no disinfection of the lateral injector and low adherence to proper hand hygiene. ${ }^{7}$

A feature that has been used to evaluate the quality of care practices, in general, is the construction and monitoring of clinical indicators, conceptualized as quantitative measures of variables, characteristics or attributes of a given process or system that allow recognizing desirable or undesirable results. ${ }^{8}$

Within this theoretical approach, a multidisciplinary team developed a manual entitled "Manual for Evaluation of Cross-Infection Control Practices", composed of 59 clinical indicators of evaluation, mainly procedural, constructed and validated as to their content, inspired by the recommendations of the Healthcare Infection Control Practices Advisory Committee, from the United States, under the consensus of its most important entities in the control of HAIs: Center for Disease and Control, Association for Professionals in Infection Control and Epidemiology, the Council of State and Territorial Epidemiologists, and the Society for Healthcare Epidemiology of America, Association of Practitioners in Infection Control, among others. These recommendations call upon the need for cross-infection control programs to start working with evaluation systems that present the results of care and not only cross-infection events. ${ }^{9}$

Despite the prevention and control measures for central venous catheter-related bloodstream infection being well established, reality points to a need for research, because, in practice, evidence shows unsatisfactory levels of performance in their application by health professionals. Thus, the form of construction of these indicators is expected to promote recognition not only for performance compliance rates of these practices, but also for concrete situations that are interfering with these results, in order to contribute to direct and specific improvement interventions.

The aim of this study was to evaluate the compliance in carrying out prevention and control practices for central venous catheter-related bloodstream infection through the application of a set of procedural clinical indicators related specifically to the risks of this event, contained in this manual.

\section{METHOD}

A cross-sectional observational study, with a quantitative approach, was developed in two 
intensive care units for adult patients at a large and highly complex private hospital in the city of Fortaleza, in the state of Ceará, Brazil, which assists patients in urgency and emergency situations.

The study was structured as per the "Manual for Evaluation of Cross-Infection Control Practices", involving the following prevention and control practices for central venous catheterrelated bloodstream infection: 1) Insertion of short-term central venous catheter containing the components: percutaneous insertion, complete surgical scrub, expanded sterile field, use of antiseptic alcoholic vehicle for preparation of the patient's skin, occlusive dressing after catheter insertion; 2) Daily registrations of indication and dwell time of the CVC;3) Adherence to care and maintenance of the CVC dressing and its devices, with the components: registration of dressing replacements, periodicity of dressing replacements as recommended by the institution, disinfection of hubs and connectors with $0.5 \%$ alcoholic chlorhexidine before handling, replacement of infusion set and transducers according to institutional recommendation; 4) Adherence to hand hygiene in situations related to vascular lines, which include: replacement of the infusion system, drug administration, replacement and application of dressing and blood collection.

Process indicators from the manual were used for data collection. ${ }^{9}$ These indicators contain worksheets to record the evaluations and an operational construct that describes and guides the application of evaluation of the practice corresponding to it. It is arranged in a concrete operation and indicates what is being evaluated and how the collection of information and its measurement should occur, aiming to ensure uniformity in the evaluation and legitimacy of empirical representation of the data, besides presenting the best available practice, scientifically based, allowing the calculation of compliance rates after evaluation. ${ }^{9}$ Its form of construction allows obtaining both the overall compliance and the compliance for the component of each practice. The overall compliance is only considered when all components of each practice are complied with in the same patient. In the case of hand hygiene, compliance was considered when the professional sanitized hands before and after performing the selected procedures, using water and antiseptic soap or alcohol gel, and noncompliance, when the professional did not sanitize them at all, or either only before or after the procedure.

The sample consisted of events, and corresponded to 2064 opportunities for evaluation of selected practices, carried out by health professionals (physicians and nurses) in hospitalized patients in both intensive care units that passed through the insertion procedure of short-term central venous catheter in the ICU, therefore excluding short-term central venous catheters inserted in other sectors of the hospital or other hospitals, patients without $\mathrm{CVC}$, and practices related to short-term central venous catheter not selected for the study. Since the insertion practices, registrations of indication and dwell time are directly related to the act of central access puncture, for the size of this sample a survey was conducted on the amount of shortterm central access punctures carried out in the period of a year (2012), in the ICU, and a total of 168 punctures were detected, resulting in an average of 10 to 14 accesses per month, being a sample of 40 accesses established for analysis of the related practices. To estimate the sample size of the other selected practices, the formula for finite population was used.

For sample definition, an $80 \%$ compliance was expected, which was defined based on studies evaluating nursing procedures and cross-infection control and prevention practices. ${ }^{10}$

Observations were carried out according to the constructs' orientations regarding the indicators for these practices, selected by the main researcher and two nursing students who were on supervised internship during the collection period, which took place between January and June 2013, through direct observation and by checking records from medical charts. The collections happened in the morning ( $8 \mathrm{am}$ to $12 \mathrm{pm}$ ), in the afternoon (2pm to $6 \mathrm{pm})$ and at night (7pm to $10 \mathrm{pm})$, Monday to Friday, being the students responsible for the collection during the day and the researcher at night, with frequency variation between shifts, excluding weekends and holidays, thus avoiding the compromising of the sample due to the sector's rate of absenteeism. It is important to stress that the students responsible for data collection were previously trained and oriented to: identify only included catheters and selected practices; register in the evaluation sheets the information obtained as the practices were carried out by health professionals; act in a way not to interfere with the 
practice and perform the evaluation in a discrete and passive manner. To mitigate the biases of observation, data collected during the first month of research were neglected, for this period was considered as a period of adjustment between the observer and the professionals who performed the selected procedures for observation.

The research project was submitted to the Research Ethics Committee of the Federal University of Ceará and approved under protocol n. $047547 / 2013$. Health professionals working in the unit, and, therefore, likely to be observed, were consulted on their availability to participate in the research and informed about the objectives of the study, data collection method and confidentiality of their identity and function. Thereby, all professionals from the healthcare staff participating in the study signed a Free and Informed Consent Form, according to Resolution n. $466 / 12$.

The data were organized in a Microsoft Excel ${ }^{\circledR}$ spreadsheet and subsequently treated by statistical analysis in the Statistic Package for the Social Sciences ${ }^{\circledR}$, and the results, presented in graphs and tables. To calculate compliance rates of the selected practices, the recommended formulas in the operational constructs of these indicators were used, through their arrangement in numerators and denominators. The denominators correspond to the total of evaluated practices and the numerators are the total number of evaluated practices that obtained compliance. Data analysis was performed using descriptive statistics. To calculate compliance rates, equations of overall compliance and from each evaluated component were employed, as recommended in the manual.

\section{RESULTS}

During the study period, a total of 2064 evaluations were carried out, related to the components of each indicator: 280 evaluations related to Indicator 1 - Evaluation of the practice of registrations of indication and dwell time of the shortterm central venous catheter (CSPI); 280 related to Indicator 2 - Evaluation of the practice of the short-term central venous insertion (CSQI); 892 related to Indicator 3 - Evaluation of the practice of adherence to care maintenance of the short-term central venous catheter dressing and its associated devices (CSCM) and Indicator 4 - Evaluation of the practices of adherence to hand hygiene in situations related to vascular lines (HMSEL). The compliance and relevant associations are described as follows.

According to indicator CSPI, compliance of each component alone shows high adherence by professionals, $80 \%$ for registration of indication and $75 \%$ for the registration of the CVC dwell time, whereupon the CVC registration of indication was performed by physicians and the registration of dwell time, by nurses.

Table 1 - Compliance and noncompliance of the practice of the catheter insertion, maintenance of its dressing and hand hygiene (indicators CSQI, CSCM and HME). Fortaleza, Ceará, Brazil, 2013

\begin{tabular}{|c|c|c|c|c|c|c|}
\hline \multirow{2}{*}{ Components } & \multicolumn{2}{|c|}{ Compliance } & \multicolumn{2}{|c|}{ Non-compliance } & \multicolumn{2}{|c|}{ Total } \\
\hline & n & $\%$ & $\mathbf{n}$ & $\%$ & $\mathbf{N}$ & $\overline{\%}$ \\
\hline \multicolumn{7}{|l|}{ Practice of the catheter insertion (CSQI) } \\
\hline Percutaneous insertion & 40 & 100 & - & - & 40 & 100 \\
\hline Use of complete medical scrub for the CVC insertion & 23 & 57.5 & 17 & 42.5 & 40 & 100 \\
\hline $\begin{array}{l}\text { Use of expanded sterile field at the time of installing } \\
\text { the catheter }\end{array}$ & 12 & 30 & 28 & 70 & 40 & 100 \\
\hline Use of antiseptic alcoholic vehicle for skin preparation & 15 & 37.5 & 25 & 62.5 & 40 & 100 \\
\hline $\begin{array}{l}\text { Presence of occlusive dressing after the catheter inser- } \\
\text { tion }\end{array}$ & 40 & 100 & - & - & 40 & 100 \\
\hline \multicolumn{7}{|l|}{ Maintenance of the catheter dressing (CSCM) } \\
\hline Registration of dressing replacements & 204 & 91.7 & 19 & 8.3 & 223 & 100 \\
\hline Periodicity of dressing replacements as recommended & 208 & 93.1 & 15 & 6.9 & 223 & 100 \\
\hline $\begin{array}{l}\text { Disinfection of hubs and connectors with } 0.5 \% \text { alco- } \\
\text { holic chlorhexidine }\end{array}$ & 39 & 17.5 & 184 & 82.5 & 223 & 100 \\
\hline $\begin{array}{l}\text { Replacement of infusion set and transducers as rec- } \\
\text { ommended }\end{array}$ & 30 & 13.5 & 193 & 86.5 & 223 & 100 \\
\hline
\end{tabular}




\begin{tabular}{|c|c|c|c|c|c|c|}
\hline \multirow{2}{*}{ Components } & \multicolumn{2}{|c|}{ Compliance } & \multicolumn{2}{|c|}{ Non-compliance } & \multicolumn{2}{|c|}{ Total } \\
\hline & $\mathrm{n}$ & $\%$ & $\mathbf{n}$ & $\%$ & $\mathbf{N}$ & $\%$ \\
\hline \multicolumn{7}{|l|}{ Practice of hand hygiene (HME) } \\
\hline Replacement of the infusion system & 23 & 10.3 & 200 & 89.7 & 223 & 100 \\
\hline Blood collection & 81 & 36.1 & 142 & 63.9 & 223 & 100 \\
\hline Drug administration & 61 & 27.1 & 162 & 72.9 & 223 & 100 \\
\hline Replacement and application of dressing & 60 & 26.9 & 163 & 73.1 & 223 & 100 \\
\hline
\end{tabular}

According to Table 1, concerning indicator CSQI, the percutaneous insertion practices and presence of occlusive dressing after the CVC insertion showed $100 \%$ compliance rates. However, the use of expanded sterile field at the time of installing the catheter $(30 \%)$ and the use of antiseptic alcoholic vehicle for skin preparation $(37.5 \%)$ had the lowest levels of compliance.

Regarding indicator CSCM, practices related to the periodicity of dressing replacements $(93.1 \%)$ and registration of dressing replacements $(91.7 \%)$ had higher compliance rates than others. Nevertheless, the practices related to the replacement of infusion set and transducers as recommended by the institution (13.5\%) and disinfection of hubs and connectors with $0.5 \%$ alcoholic chlorhexidine $(17.5 \%)$ had low compliance rates.

Indicator HME presents practices with the worst compliance rates when compared to other indicators, especially regarding the practice of hand hygiene before and after replacing the infusion system, with the lowest compliance rate of all observed practices $(10.3 \%)$.

It is noteworthy that most professionals did not perform hand hygiene at any time, as the high rates of noncompliance can be seen in all practices: replacement of the infusion system $(89.7 \%)$, drug administration $(72.9 \%)$ and replacement and application of dressing (73.1\%). These low compliance rates show a low uptake of health professionals in relation to hand hygiene procedures, considered one of the main factors for the transmission of cross-infection.

Each separate practice compliance rate was calculated for each indicator evaluated in this study, as demonstrated, in addition to the calculation of each indicator's overall compliance rate, using the formulas from the evaluation indicators from the spreadsheets. This required all components from each one of them to be complied with in the same patient. If the practice of one of them was not performed correctly, the indicator was scored as noncompliant (Figure 1).

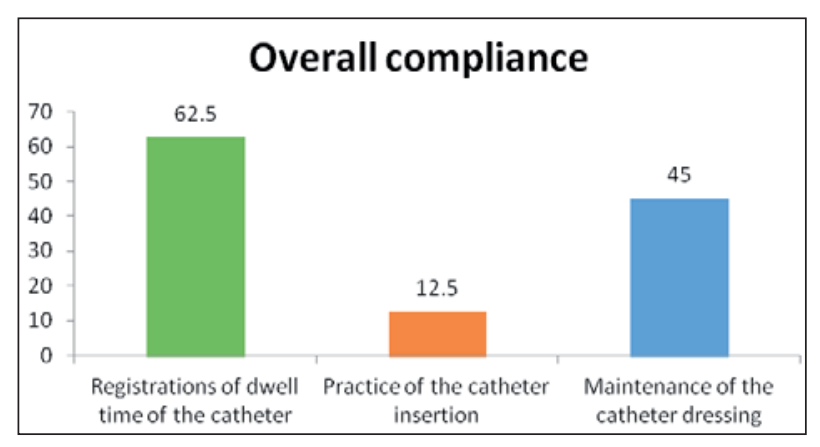

Figure 1 - Overall compliance of indicators CSPI, CSQI and CSCM. Fortaleza, Ceará, Brazil, 2013

According to Figure 1, indicator CSPI had the greatest overall compliance rate, $62.5 \%$, followed by indicator CSCM, with only $45 \%$, and indicator CSQI presented $12.5 \%$. However, the one with the lowest overall compliance rate, not presented in the table above for being null, was indicator HMSEL.

\section{DISCUSSION}

The evaluation of quality of the procedures with the use of indicators is important and necessary because their results provide data that enable the development of guidelines and standards on the care provided, focusing on improving processes and procedures. ${ }^{11}$

The practice of the catheter indication registration showed the expected compliance because the hospital where the study was conducted, due to private service features, encourages professionals to register all procedures on the medical chart, so that they can be authorized by the patient's health plan, thus avoiding losses and glosses. There is also a form in which nurses control all invasive devices, such as probes, drains and catheters, in relation to their dwell time, to get a sense of whether or not to replace them, besides, of course, withdrawing.

The quality of registration of the care provided reflects the quality of care and labor productivity. Based on these records, better healthcare 
practices can be permanently built, besides implementing actions to improve operational results. ${ }^{12}$

The registration of the CVC dwell time is extremely important in the prevention and control of bloodstream infection related to the use of $\mathrm{CVC}$, because knowing the catheter dwell time makes it possible to evaluate the need to replace it or not. According to the literature, the routine replacement of the CVC at regular time intervals have not influenced significantly the reduction of rates. However, if it is left for longer than 1-2 weeks, the rate of CVC-associated infection is higher. ${ }^{13}$

According to the results found, the records related to indicator CSQI obtained a low overall compliance rate $(12.5 \%)$ due to the absence of use of antiseptic alcoholic vehicle for skin preparation prior to puncture $(37.5 \%)$ and of expanded sterile field at the time of installing the catheter $(30 \%)$.

The skin antisepsis with antiseptic alcoholic vehicle is a very important aspect in the prevention and control of bloodstream infection. A study conducted in the operating room of a teaching hospital in São Paulo had 100\% compliance during the observation of practices related to vascular catheter implants, utilizing $0.5 \%$ alcoholic chlorhexidine for skin preparation. ${ }^{14}$

According to a randomized controlled trial study with 538 catheters, of which 481 presented culture results, when comparing the povidone iodine solution to the chlorhexidine solution, a $50 \%$ decrease in the incidence of colonization and a lower tendency of bloodstream infection rates related to the catheter were associated, regardless of the risk factors. ${ }^{15}$

In another randomized controlled trial study comparing $2 \%$ chlorhexidine gluconate with $10 \%$ povidone iodine and 70\% isopropyl alcohol, chlorhexidine compared with povidone iodine reduced colonization by about $69 \%$, but did not present statistically significant reduction of blood infection. Compared with $70 \%$ ethanol, it showed no statistical significance in the reduction of colonization or bloodstream infection. ${ }^{16}$

Indicator CSCM refers to the adherence to care and maintenance of CVC dressings and associated devices, but in the overall compliance evaluation this indicator reached $45 \%$. In the individual compliance of each practice, it was observed that the practices related to disinfection of hubs and connectors with $0.5 \%$ alcoholic chlorhexidine $(17.5 \%)$ and to the replacement of infusion set and transducers as recommended $(13.5 \%)$ were the ones that had the worse results.
A study conducted by nursing professionals about the adherence to measures of prevention and control of peripheral vascular access infection found that, in most procedures, the professionals did not adopt the recommendation of previous disinfection with $70 \%$ alcohol as they administered drugs in catheters of immunized patients. The results showed that in $68 \%$ of procedures the nursing professionals administered drugs using the lateral injector without prior disinfection of the connector with $70 \%$ alcohol. ${ }^{17}$

The disinfection of connectors before manipulation with a product containing alcohol is an important step in the prevention of contamination of the central venous catheter and consequent bloodstream infection because, first of all, the contaminant present on the surface will be forced by the intraluminal route. Secondly, the internal chambers (differential septal penetration), once contaminated, are impossible to be disinfected. ${ }^{16}$

Alcoholic chlorhexidine must be the product of choice for disinfecting hubs and connectors before access because, based on studies, it was proven to be the most efficient when compared to other antiseptic alcoholic vehicles. ${ }^{18}$

With regard to the practice related to the periodicity of dressing replacements as recommended by the institution where the study was conducted, the catheter insertion dressing can be performed either conventionally (sterile gauze and adhesive tape) or with transparent or semipermeable film. The dressing replacement period will also vary according to the type used, i.e., sterile gauze and adhesive tape should be replaced every 24 hours, and, in case of using a transparent film, every seven days, and, of course, it should be immediately replaced whenever wet or dirty.

All dressings are applied by nurses, in the morning, after personal hygiene, always avoiding to wet it. As soon as the central venous access is punctured, the conventional dressing with sterile gauze and Micropore ${ }^{\circledR}$ is applied, and, after 24 hours, if there is no local bleeding, it is replaced by a semipermeable dressing impregnated with chlorhexidine, being replaced every seven days, or before, in case it gets loose or presents secretion. Cases in which patients present reaction to chlorhexidine, a simple semipermeable dressing is used, with a change period of five days, or whenever necessary.

The gauze and tape and transparent polyurethane dressings have been widely studied lately by randomized clinical trials, and there is 
no strong evidence to support the use of one or the other, according to data from a meta-analysis on the subject. ${ }^{19}$

Gauze and tape are the most simple and common dressings, made of woven cotton fibers; indicated for diaphoretic patients and for bleeding accesses or accesses that present gingival crevicular fluid, as they have good absorption capacity. Its disadvantage is that, due to the need for attachment of the adhesive tape, local reaction can be developed by the patient. Also, it can make it difficult to visualize the catheter exit orifice for inspection and it can absorb external moisture. ${ }^{20}$

Regarding the chlorhexidine antimicrobial dressing, knowledge is still incipient, making it difficult to incorporate this new technology to the nursing practice. A clinical trial with 1,636 patients compared the chlorhexidine antimicrobial dressing and transparent polyurethane film, with a reduction of cases of IPCS in the first group. ${ }^{21}$

As for the practice of hand hygiene, noncompliance was attributed when hand hygiene was performed either only before or after, or when the professional finished the procedure under evaluation and then operated another care procedure without performing hand hygiene, withdrew from the patient's bed to another area, changed gloves or superimposed procedure or sterile gloves on his already gloved hands.

Hand hygiene is indicated before administering drugs orally and preparing nebulization, before and after performing hospital work, physiological or personal acts and functions, before and after handling each patient, preparing materials or equipment, collecting specimens, administering injectable drugs and hygienizing and changing patients' clothes. ${ }^{22}$

The practice of hand hygiene is recognized as the most effective measure for the prevention of HAIs, as demonstrated by studies that show a reduction in the transmission of pathogenic microorganisms in parallel with the increased adherence of the professionals to the procedure. Despite its epidemiological importance, promoting adherence to this practice is a challenge. ${ }^{23}$

Different causes are attributed to the negligence of health professionals towards the hand hygiene technique, sometimes related to their beliefs and myths, lack of nearby sinks and adequate resources, skin reactions on the hands, lack of motivation, time, human resources, preparation and awareness about the importance of the hands in the transmission of microorganisms. ${ }^{22}$
Some authors reported that, according to their experience and the review of the conducted literature, there are several factors, pointed out by health professionals, that interfere in this decision making about the adherence or not to the hand hygiene practice, such as: forgetfulness, ignorance of its importance, distance from sink, skin rash, insufficient time and lack of materials. ${ }^{24}$

A qualitative study, based on structured interviews, attended by 65 nurses, physicians and medical students in intensive care and surgery services from five hospitals in Holland, considered: priority activities, lack of equipment and accessible materials, lack of time, forgetfulness, the lack of scientific evidence about the importance of hand hygiene in preventing cross-infections and the lack of positive role models and norms. ${ }^{25}$

\section{CONCLUSION}

This study evaluated the compliance of control and prevention practices for bloodstream infection associated with short-term central venous catheter through the application of process indicators (CSQI, CSPI, CSCM, HMSEL), which made it possible to identify the level of adherence to these practices among the professional categories.

The expected compliance of $80 \%$ was not achieved by any of the indicators. However, the indicator that evaluated the practice of registrations of indication and dwell time of the short-term central venous catheter (indicator CSPI) was the closest to the expected compliance. The other indicators, despite not having obtained the expected overall compliance, had some of the components outperforming this index, such as: percutaneous insertion, use of occlusive dressing after the catheter insertion, registration of dressing replacements, periodicity of dressing replacements as recommended and registration of the short-term central venous catheter puncture indication, which shows that some recommendations are well established.

According to the results reported in this study, we believe to have identified relevant factors to explain the professionals' adherence or not, regarding the prevention and control practices for infections related to short-term central venous catheter, from the application of process indicators, which pointed out that the norms, despite being instituted and known by all, are still not adequately complied with in practice.

It is necessary to stress the importance of developing educational programs grounded on 
scientific evidence, conducted by researchers that aim to combine theory with practice, in order to change this reality. Therefore, an alliance between the continuing education service and Hospital Infectioon Control Commission is required, with care professionals seeking to analyze the context of reality, so that these changes can be accepted and well performed by health professionals as an essential practice in their routine.

We believe that the results reported here are likely to contribute to the development of improvement actions for the care practice, such as the creation of educational strategies and continuous evaluation of care, aimed at reducing bloodstream infection related to the use of $\mathrm{CVC}$, and that can be easily applicable and reproducible in other sectors that have patients with these characteristics.

\section{REFERENCES}

1. Ferreira MVF, Andrade D, Ferreira AM. Controle de infecção relacionada a cateter venoso central impregnado com antissépticos: revisão integrativa. Rev Esc Enferm USP. 2011; 45(4):1002-6.

2. Medeiros EAS. Efeito de um programa educacional na redução de infecção da corrente sanguínea relacionada ao cateter venoso central. Rev Paul Pediatr. 2010 Oct-Dec, 28(4):290-1.

3. Horan TC, Andrus M, Dudeck MA. CDC/NHSN surveillance definition of health care-associated infection and criteria for specific types of infections in the acute care setting. Am J Infect Control, 2008 Jun; (36):309-32.

4. Mermel LA, Allon M, Bouza E, Craven DE, Flynn P, $\mathrm{O}^{\prime}$ grady NP, et al. Clinical practice guidelines for the diagnosis and management of intravascular catheter related infection: 2009 Update by the Infectious Diseases Society of America. Clin Infect Dis. 2009 June, 49(1):1-45.

5. Wolf HH, Leithäuser M, Maschmeyer G, Salwender $\mathrm{H}$, Klein U, Chaberny I, et al. Central venous catheter-related infections in hematology and oncology: guidelines of the Infectious Diseases Working Party (AGIHO) of the German Society of Hematology and Oncology (DGHO). Ann Hematol. 2008 Jul; 87(11):863-76.

6. Centers for Disease Control and Prevention-CDC. Guidelines for the prevention of intravascular catheter-related infections, 2011.

7. Cardoso SR, Pereira LS, Souza ACS, Tipple AFV, Pereira MS, Junqueira ALN. Antissepsia para administração de medicamentos por via endovenosa e intramuscular. Rev Eletr Enferm [online]. 2006 [acesso 2014 Dez 02]; 8(1). Disponivel em: http:// www.fen.ufg.br/revista/revista8_1/original_10. htm
8. Ottoni ACL. Utilização de indicadores de qualidade como ferramenta no planejamento da construção de nova estrutura física de UTI adulto. Rev Adm Saúde. 2009 Jul-Set, 11(44):127-32.

9. Secretaria da Saúde do estado de São Paulo. Divisão de Infecção Hospitalar, Centro de Vigilância Epidemiológica. Manual de avaliação da qualidade de praticas de controle de infecção hospitalar. São Paulo (SP): Secretaria da Saúde do estado de São Paulo; 2006.

10. Nonino EAPM. Avaliação da qualidade dos procedimentos de enfermagem-banho e curativosegundo o grau de dependência assistencial dos pacientes internados em um Hospital Universitario [tese]. Ribeirão Preto (SP): Escola de Enfermagem de Ribeirão Preto, Programa de Pós-Graduação em Enfermagem; 2006.

11. Vituri DW, Matsuda LM. Content validation of quality indicators for nursing care evaluation. Rev Esc Enferm USP. 2009 Dec, 43(2):1174-80.

12. Setz VG, Innocenzo MD. Avaliação da qualidade dos registros de enfermagem no prontuário por meio de auditoria. Acta Paul Enferm. 2009, 22(3):313-7.

13. O'grady NP, Alexander M, Burns LA, Dellinger EP, Garland J, Herad SO. Summary of recommendations: Guidelines for the Prevention of Intravascular Catheter-related Infections. Clin Infec Dis. 2011, 52(9):1087-99.

14. Jardim JM. Intervenção educacional na redução da taxa de infecção da corrente sanguínea em Unidade de Terapia Intensiva adulto: revisão integrativa [monografia]. São Paulo (SP): Escola de Enfermagem da Universidade de São Paulo. Programa de PósGraduação em Enfermagem; 2010.

15. Evans HL, Dellit TH, Chan J, Nathens AB, Maier RV, Cuschieri J. Effect of Chlorhexidine Whole-Body Bathing on Hospital-Acquired Infections Among Trauma Patients. Arch Surg. 2010 mar, 145(3):240-6.

16. Btaiche IF, Kovacevich DS, Khalidi N, Papke LF. The effects of needleless connectors on catheter-related bloodstream infections. Am J Infect Control. 2011 May;39(4):277-83.

17. Martins KA, Tipple AFV, Souza ACS, Barreto RASS, Siqueira KM, Barbosa JM. Adesão às medidas de prevenção e controle de infecção de acesso vascular periférico pelos profissionais da equipe de enfermagem. Ciênc Cuid Saúde. 2008 Out-Dez, 7(4):485-92.

18. Andrade A, Cardoso PP, Carones N, Ferreira M. Nursing protocol - Prevention of CVC associated bacteremia. Rev Port Med Int. 2010; 17(1):55-9.

19. Webster J, Gillies D, O'Riordan E, Sherriff KL, Rickard $\mathrm{CM}$. Gauze and tape and transparent polyurethane dressings for central venous catheters. Cochrane Database Syst Rev. 2011 Nov 9; (11):CD003827.

20. Pedrolo E, Danski MTR, Mingorance P, Lazzari LSM, Johann DA. Ensaio clínico controlado sobre o 
curativo de cateter venoso central. Acta Paul Enferm. 2011, 24(2):278-83.

21. Timsit JF, Schwebel C, Bouadma L, Geffroy A, Garrouste-Orgeas M, Pease S, et al. Chlorhexidineimpregnated sponges and less frequent dressing changes for prevention of catheter-related infections in critically ill adults: a randomized controlled trial. JAMA. 2009 Mar 25; 301(12):1231-41.

22. Martinez MR, Campos LAAF, Nogueira PCK. Adesão à técnica de lavagem de mãos em Unidade de Terapia Intensiva Neonatal. Rev Paul Pediatr. 2009, 27(2):179-85.

23. Belela-Anacleto ASC, Sousa BEC, Yoshikawa JM, Avelar AFM, Pedreira MLG. Higienização das mãos e a segurança do paciente: perspectiva de docentes e universitários. Texto Contexto Enferm [online]. 2013 Out-Dez [acesso 2014 Dez 02]; 22(4):901-8. Disponível em: http:/ / www.scielo.br/scielo.php?pid=S0104-07072013000400005\&script=sci_arttext

24. Santos TCR, Roseira CE, Piai-Morais TH, Figueiredo RM. Higienização das mãos em ambiente hospitalar: uso de indicadores de conformidade. Rev Gaúcha Enferm. 2014; 35(1):70-7.

25. Erasmus V, Brouwer W, Van Beek EF, Oenema A, Daha TJ, Richardus JH, et al. A qualitative exploration of reasons for poor hand hygiene among hospital workers: lack of positive role models and of convincing evidence that hand hygiene prevents cross-infection. Infect Control Hosp Epidemiol. 2009; 30(5):415-9. 